\title{
MINERALOGICAL AND STABLE ISOTOPIC STUDY OF ANCIENT WHITE MARBLE QUARRIES IN LARISA, THESSALY, GREECE
}

\author{
Melfos $\mathrm{V}$. \\ Department of Mineralogy, Petrology, Economic Geology, School of Geology, Aristotle University \\ of Thessaloniki, GR-546 24, Thessaloniki, Greece melfosv@geo.auth.gr
}

\section{ABSTRACT}

The present work focuses on the white marbles which were extracted in Larisa prefecture, Central Greece, during the antiquity. Three characteristic ancient quarries, which are located in the Kastri village (Aghia area), in Kalochori (Sykourio area) and in Gonnoi (Tembi area), were selected for the present study. Data obtained from the extraction techniques are combined with the geological, mineralogical and stable isotopic features in order to determine these marble ancient sources. The average $\delta^{13} \mathrm{C}$ and $\delta^{18} \mathrm{O}$ values of the Kastri marble are $+2.80 \%$ and $4.51 \%$ and of the Kalochori marble $+0.87 \%$ and $-8.33 \%$. At Gonnoi ancient quarrying sites, the isotopic results are heterogeneous: $+1.05 \%$ o $\delta^{13} \mathrm{C},-4.65 \%$ o $\delta^{18} \mathrm{O}$ for Gonnoi $1 \mathrm{~A},+1.89 \%$ $\delta^{13} \mathrm{C},-7.97 \% \delta^{18} \mathrm{O}$ for Gonnoi $1 \mathrm{~B},+2.27 \%$ o $\delta^{13} \mathrm{C},-3.12 \% \delta^{18} \mathrm{O}$ for Gonnoi 3 .

\section{INTRODUCTION}

The white marble, an attractive and brilliant stone, is strongly related to the social, religious and economic life of Greeks, from the Prehistoric period until today. Especially, throughout antiquity, from Classical and Hellenistic time to early Byzantine period, marble affected the rapid evolution of the technology and economy of the ancient Greeks. Theophrastus $\left(4^{\text {th }}\right.$ century B.C.) refers that "one of the most well-known characteristics of the stones is the possibility for treating them, and some of them can be carved, sculptured and chiselled or cut with a saw" (Theophrastus, About Stones, 5). Since the ancient Greeks had deep knowledge of the physical properties of the marble, they expressed the harmony of proportion in the buildings and sculptures construction. It was therefore admirably suited for both architectural and sculptural work, and for epigraphical purposes.

Important marble producing centres were spread around the Aegean sea and provided unique varieties of raw materials in all the Mediterranean area. Famous marble quarries operated in Paros, Penteli, Hymettus, Naxos, Thasos, Doliana, Skyros, Euboea, Prokonnesos (Marmaras sea), Ephesos, Aphrodisias, Dokimia (Orlandos 1958, Craig \& Craig 1972, Herz 1987, Tsirambides 1996).

The extensive use of the marbles as building materials by the Greeks, began during the $7^{\text {th }}$ century B.C. Marble was extracted from open pits with straight rock faces and stepwise excavations. The quarrymen selectively mined marbles of high quality and purity, in places where the slopes of the mountains were steep.

In modern science, it is very important to know the exact sources of the raw materials used for the manufacture of the marble artifacts and buildings in antiquity, because this permits to come to important conclusions about the quarrying techniques, the trade patterns, the distances of transportation and the networks of exchange and communication between different ancient communities. The determination of the origin of the white-marble artifacts by only macroscopic examination (such as colour and crystallinity) is rather difficult, as large variations of the physical properties can be observed even for marbles from the same quarry or quarrying area.

The most accurate methods which have been developed for distinguishing white marbles of different origin, are petrographic analysis, stable isotopes $\left({ }^{13} \mathrm{C}\right.$ and $\left.{ }^{18} \mathrm{O}\right)$ and sometimes trace element analysis and Electron Paramagnetic Resonance spectroscopy (Craig \& Craig 1972, Lazzarini 1980, Herz 1987, Tsirambides 1996, Maniatis \& Polikreti 2000, Polikreti \& Maniatis 2001, among others). The suitability of these techniques is based on the development of extensive data-bases from 
known ancient marble sources and the statistical treatment of the measured parameters. Important additional requirement is the small amount of sample needed. Especially, isotopic ratios of $\mathrm{C}$ and $\mathrm{O}$ provide usable signatures for determining the provenance of marbles. Isotopic analysis involves measuring of the ${ }^{13} \mathrm{C} /{ }^{12} \mathrm{C}$ and ${ }^{18} \mathrm{O} /{ }^{16} \mathrm{O}$ ratios in samples and the results are expressed in terms of the deviation from a conventional standard. This deviation, called $\delta$, is expressed as $\delta^{13} \mathrm{C}$ and $\delta^{18} \mathrm{O}$ in parts per thousand (\%o or per mil) and forms the isotopic signature. The values exhibit a relatively restricted range in each quarry area or limited parts of a geological formation (Craig \& Craig 1972, Herz 1987).

The present study focuses on three white marble quarries in Larisa prefecture (Thessaly county, central Greece) and aims in characterizing the variations of the petrographical and stable isotope ratios $\left({ }^{13} \mathrm{C}\right.$ and ${ }^{18} \mathrm{O}$ ). These quarries are located in the Kastri village (Aghia area), in Kalochori (Sykourio area) and in Gonnoi (Tembi area), and are considered to be of exceptional cultural interest. Previous studies on ancient quarries of Larisa have been carried out by Germann et al. (1980) and Melfos et al. (2002), who presented microscopic, geochemical and isotopic results.

\section{GEOLOGICAL SETTING}

The geology of the Larisa district is dominated by metamorphosed Paleozoic-Mesozoic rocks, which belong to the Pelagonian zone (Fig. 1, 4). The Paleozoic crystalline basement (gneisses, amphibolites, schists) in Eastern Thessaly is overlain by the composite Pelagonian nappe (Migiros 1983, Kilias \& Mountrakis 1989, Caputo 1990, Reischman et al. 2001). The Pelagonian nappe comprises: i) The Paleozoic crystalline and magmatic masses of Voras, Vernon and PieriaKamvounia mountains as well as those outcropping further to the south (Othris, Pelion, Skiathos and N. Evia), ii) The Permo-Triassic volcano-sedimentary series (amphibolites, mica-schists, gneiss-schists) and the Triassic-Jurassic carbonates (marbles) which are non- to only weakly metamorphosed at the western margin and more intensely metamorphosed at the eastern margin of the Pelagonian nappe, iii) The serpentinites, characterised by Late Jurassic-Early Cretaceous deformation, iv) The transgressive Cretaceous crystalline limestones that pass upwards into Palaeocene flysch.

Granites, orthogneisses and metapilites are predominant among the pre-Alpine lithologies and constitute the crystalline basement of the Pelagonian zone. Geochronology of the plutonic rocks outcropping in Elassona, Verdikoussa and Deskati areas (southwest of Mt. Olympos) as well as in northern Pelagonian zone, revealed that they are of Late Paleozoic age (225 to $302 \mathrm{Ma}$ ) and they resulted from the Hercynian magmatism (Katerinopoulos et al. 1998, Koronaios et al. 2000, Reischman et al. 2001). According to Reischman et al. (2001) the magmatic rocks are younger than the basement gneisses of the Pelagonian zone.

Intensive tectonism and shear deformation during the Early Cretaceous and Tertiary brought about multiple zones of mylonitization and imbrication, and thrusting of the units from east to west (Koukouvelas 1994, Reischman et al. 2001). An extended ophiolitic transgressive breccia is located close to the Omorphochorion village at the Chasambali hill.

The studied marbles in Kastri and Kalochori areas belong to the of Upper Cretaceous Aghia marble unit, whereas the marbles in the Gonnoi area are part of the crystalline basement of Late Paleozoic-middle Triassic age.

\section{MATERIAL AND METHODS}

Fresh white marble samples were collected from the studied ancient quarries in Kastri, Kalochori and Gonnoi areas. A total of 10 thin and polished-thin sections of the rock samples were mineralogically studied by optical microscopy at the Department of Mineralogy. Petrology, Economic Geology, University of Thessaloniki. Additionally, X-ray diffraction (XRD) was applied in order to distinguish calcite from dolomite and to verify the related abundances in each sample. Eighteen fresh marble samples were analyzed isotopically to determine their carbon and oxygen ratios. The isotopic analyses were carried out at the Department of Geology, Royal Holloway University of London, United Kingdom. 


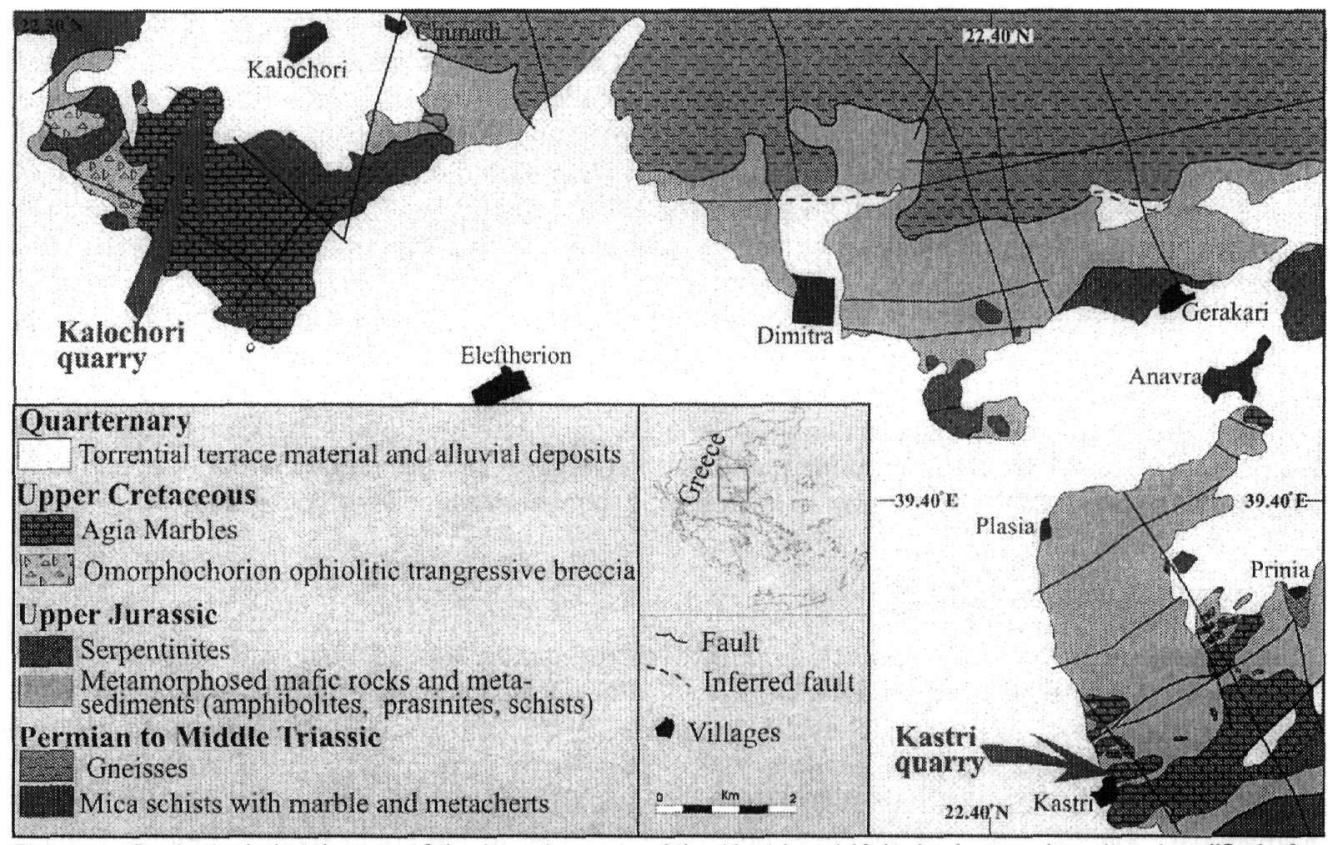

Figure 1. Geological sketch map of the broader area of the Kastri and Kalochori quarrying sites (modified after Katsikatsos et al. 1981).

\section{HELLENISTIC AND ROMAN MARBLE QUARRIES IN THE KASTRI VILLAGE}

Five ancient white marble quarries are found on the flanks of the mountain Mavrovounio and very close to the ancient Bibois lake (the modern drained Karla lake), close to the Kastri village, 25 $\mathrm{km}$ east of Larisa city (Fig. 2a,b). The rocks belong to the Aghia marble unit (Fig. 1), which is divided into two subunits. The lower subunit consists of platy black marble horizons with schist intercalations, passing gradually into the upper subunit, which comprises massive white recrystallized marbles with crystalline dolomite intercalations (Koukouvelas 1994). These rocks are suggested to be deformed crystalline reef limestones of Upper Cretaceous age (Godfriaux 1968).

The Kastri ancient quarries belong to the upper subunit of the Aghia marbles. The marble has a white to white-grey colour and in some cases grey-green-coloured thin orientated stripes $(2-4 \mathrm{~cm}$ thick) are observed parallel to the schistosity. It is a coarse-grained marble with crystals up to $3 \mathrm{~mm}$ long. Based on the microscopic and XRD study, the marble consists mainly of calcite, with quartz, white mica and chlorite as accessory minerals (Fig. 3a). The marble is characterised by a high degree of preferred orientation of the calcite crystals which are considerably distorted by elongation, flattening and bending as a result of intensive strain.

A detailed study of the Kastri quarries revealed the extraction techniques of the marble blocks during antiquity. The rock faces still bear the tool marks left by the pickaxes and the pointed chisels (Fig. 2c). The technique was simple and depended on the geological and structural features of the rock, such as bedding, cleavage, faults and cracks.

The main quarry has a height of $20-25 \mathrm{~m}$ above the present level of the ground floor, which is covered by a thick layer of debris. The extraction zone has a roughly west-east orientation and covers an area $50 \mathrm{~m}$ long and $25 \mathrm{~m}$ wide. The marble was quarried in large massive rectangular stone slabs and monoliths, e.g. $2.50 \mathrm{~m} \times 1.20 \mathrm{~m}, 3.70 \mathrm{~m} \times 1.50 \mathrm{~m}$ and $3.20 \mathrm{~m} \times 1.30 \mathrm{~m}$, and 0.80 to 1.00 $\mathrm{m}$ thick. Extraction proceeded stepwise, first by cutting a bench of the length required for the block (Fig. 2d). By hacking a channel, up to $25 \mathrm{~cm}$ wide, around the perimeter of the potential marble block, the latter was eventually disengaged from the rock mass. This was achieved by undercutting the block transversally, chiselling out small cylindrical cavities, up to $10 \mathrm{~cm}$ long, with pointed chisels, and placing iron or sometimes wooden wedges in the cavities. The next step was to split off the 


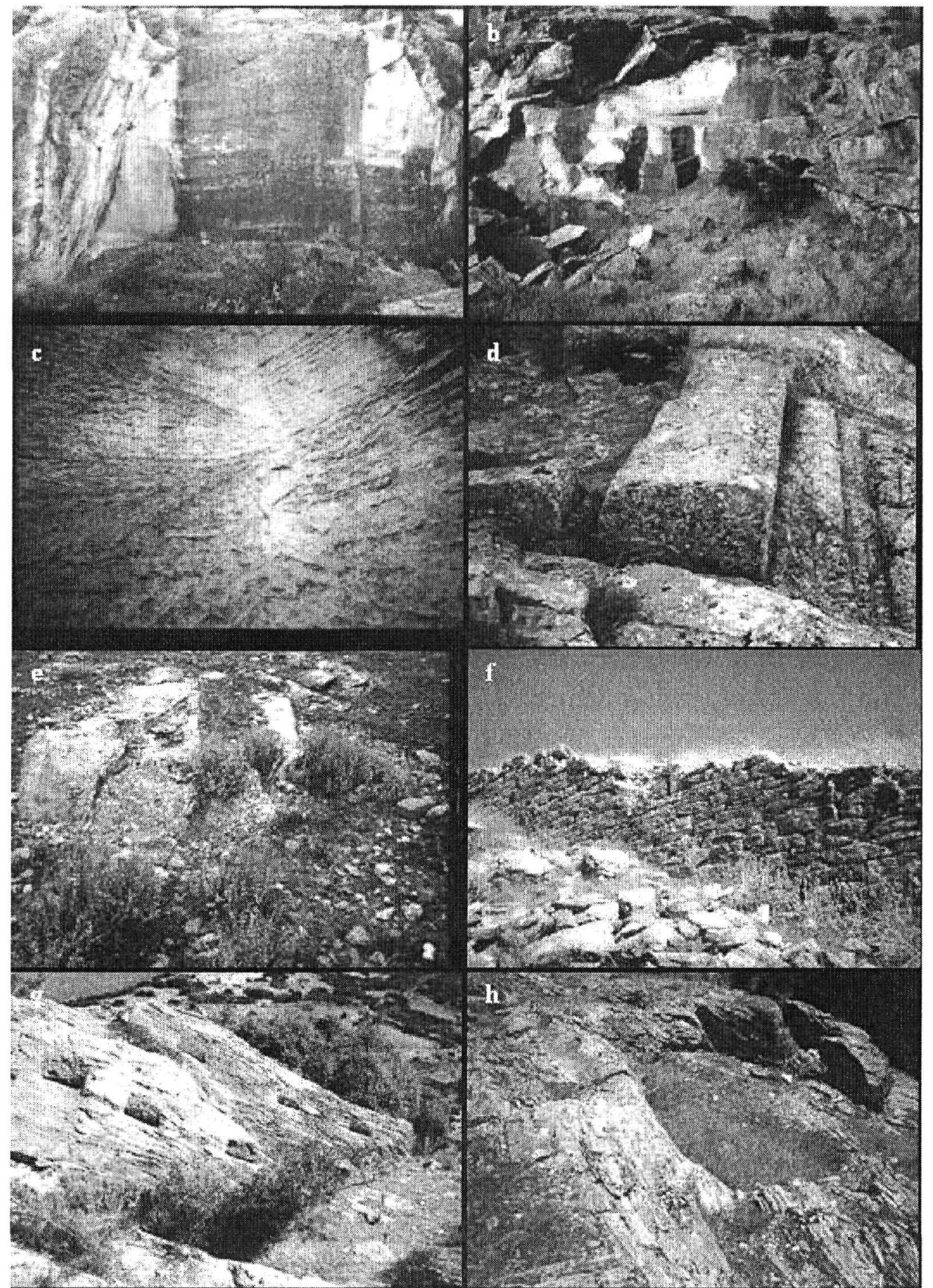

Figure 2. (a-b) Rock faces of the ancient marble quarry in Kastri, (c) Tool traces on the marble in the Kastri ancient quarry, (d) Marble slab left uncut insitu, (e) The ancient marble quarry in Kalochori, (f) The archaic city wall, ancient Gonnoi, (g) Cavities, $40 \mathrm{~cm}$ long, where wedges were placed for cutting the marble, ancient Gonnoi, first quarry site, (h) A small quarry, ancient Gonnoi, second extraction zone. 

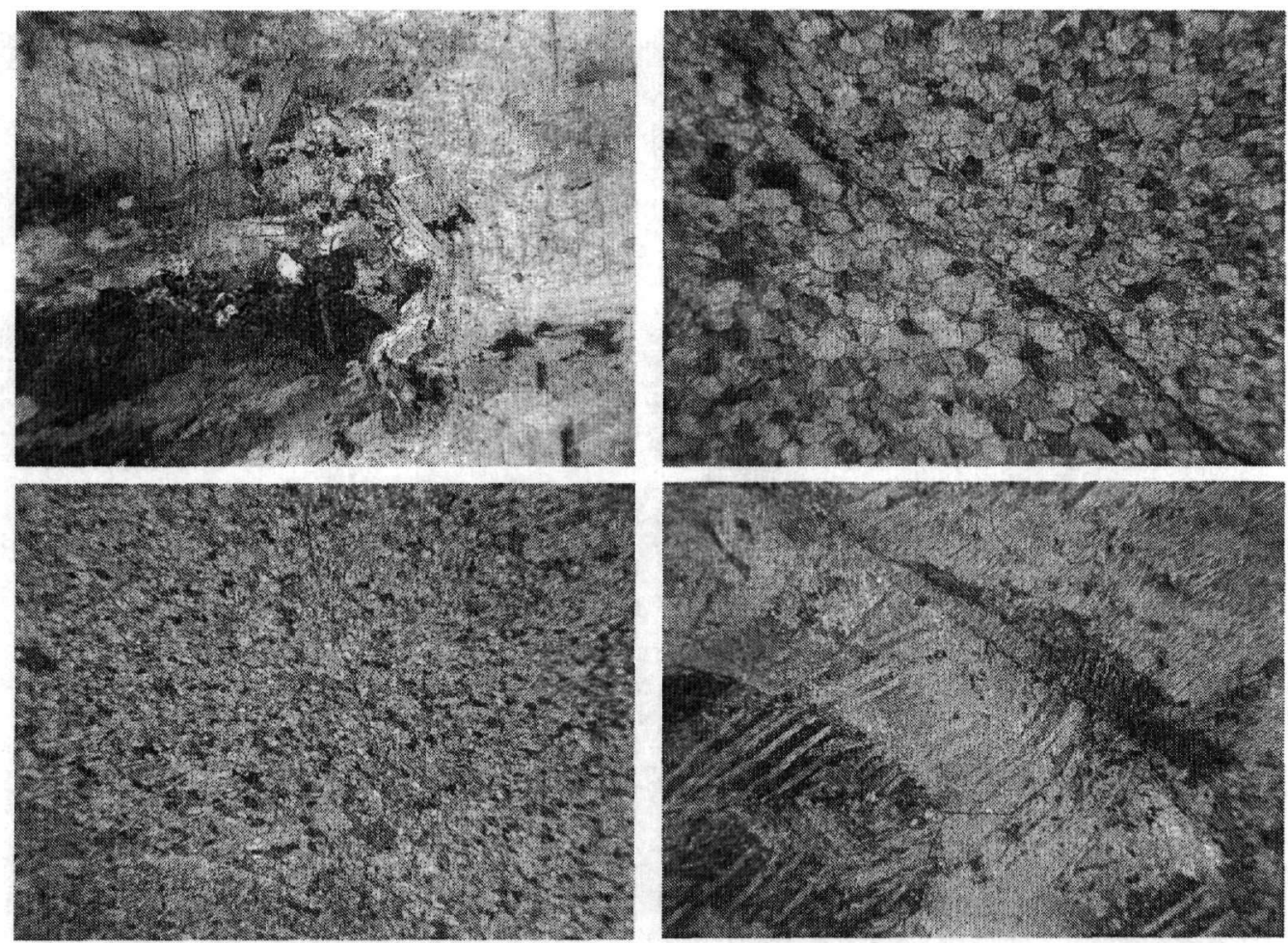

Figure 3. Photomicrographs ( $\mathrm{N}+$, figure length: $3 \mathrm{~mm}$ ) of thin sections of the Larisa quarries white marbles. (a) coarse-grained calcite intergrown with white mica, Kastri quarry, (b) equalgranural calcite crystals and a white mica vein, Kalochori quarry, (c) small-sized dolomite-calcite grains, Gonnoi $1 \mathrm{~A},(\mathrm{~d})$ strong deformed coarse-grained calcite crystals, Gonnoi 1B.

block from the bed-rock, by hammering the wedges. Material extracted from the quarry was roughly worked by sculpturing in the quarry area, in order to give an approximate shape to the block for an easier transportation. This suggestion is supported by the observed spoil heap, in the form of a horizontal plateau, in front of the quarry, as well as by the presence of a broken column left in the quarry.

Three smaller quarries are observed in the same extraction zone and very close to the main quarry. The quarrying method is exactly the same, and in one of them, with dimensions $16 \mathrm{~m}$ long, has been dug up along a big fault. In another small quarry, $15 \mathrm{~m} \times 10 \mathrm{~m}$, big marble blocks have been left in situ. The slab monoliths left uncut, are $3 \mathrm{~m}$ long, $0.80 \mathrm{~m}$ wide and $0.60 \mathrm{~m}$ thick. The surrounding channel is $25-30 \mathrm{~cm}$ wide and the cavities dug for putting the wedges are $15 \mathrm{~cm}$ long. Four to five successive extraction levels have been observed in this small quarry. It is important that all the marble slabs were cut parallel to the slope of the ground floor $\left(30-40^{\circ}\right.$ inclination).

Dating of the operations of the Kastri quarry is not precisely known, although it is ascertained that quarrying works were held mainly during Hellenistic and Roman times. The raw materials were used for the construction of the seats and parts of the stage and the cavea of the ancient theatre in Larisa are from the Kastri marble quarry. The theatre, which lies on the south slope of the hill called "Phrourion" (Fortress), was built at the end of the 3rd century B.C. and continued to be used in the Roman period. The quarry provided marbles also for the funerary stelaes and inscription manufacturing found in the area of Larisa. The extraction technique and the cutmarks still preserved on the rock faces are similar to those from the white marble quarries in Maronia area of Thrace (Melfos \& Vavelidis 2000), operated during the same period.

Modern extraction workings for exploitation of the white marble have destroyed a great part of the ancient quarry, and together the significant witnesses of the past and the used ancient technol- 
ogy. Additionally human activities like bee-feeding and dumping rubbish at the entrance of the quarry cause big problem in approaching this monument of the ancient technology.

\section{ANCIENT MARBLE QUARRIES IN THE KALOCHORI VILLAGE}

Close to the Kalochori village at the Sykourio area, $15 \mathrm{~km} \mathrm{NE}$ of Larissa city, a few traces of an ancient quarry of white marble are still observed today (Fig. 2e). The area is located near the Chasambali district, where the very important and famous green Thessalian stone quarries exist. Columns and other architecture elements, made of the Chasambali ophiolitic breccia, were transported throughout the Roman Empire and in Byzantium, especially during the Justinianus time. The ancient white marble quarry have been totally severed, due to the modern quarrying works which were held in the area by English, Italian and Greek companies between 1860 and 1980, demonstrating the extensive damage of such an important cultural monument.

Geologically the white marble belongs to the Aghia marble unit (Fig. 1). It is a fine-grained marble $(<0.5 \mathrm{~mm}$ long crystals), with a white colour. XRD and microscopic investigation revealed that the main mineral is calcite, with minor dolomite and traces of white mica (Fig. 3b).

Dating of the quarrying operations in Kalochori is almost impossible due to the lack of ancient marks on the extraction walls. It is possible that quarrying works were held mainly during the Hellenistic and Roman time, the same period with the Kastri quarries operation or at the Roman and early Byzantine times, as the green Thessalian stone quarries at the adjacent Chasambali area.

\section{ANCIENT MARBLE QUARRIES AT GONNOI}

Ancient Gonnoi, an important city of Perrhaibia, is located $25 \mathrm{~km}$ north of Larisa, on the left bank of the river Pineios, at the western entrance to the Tempi pass and at the southern spurs of

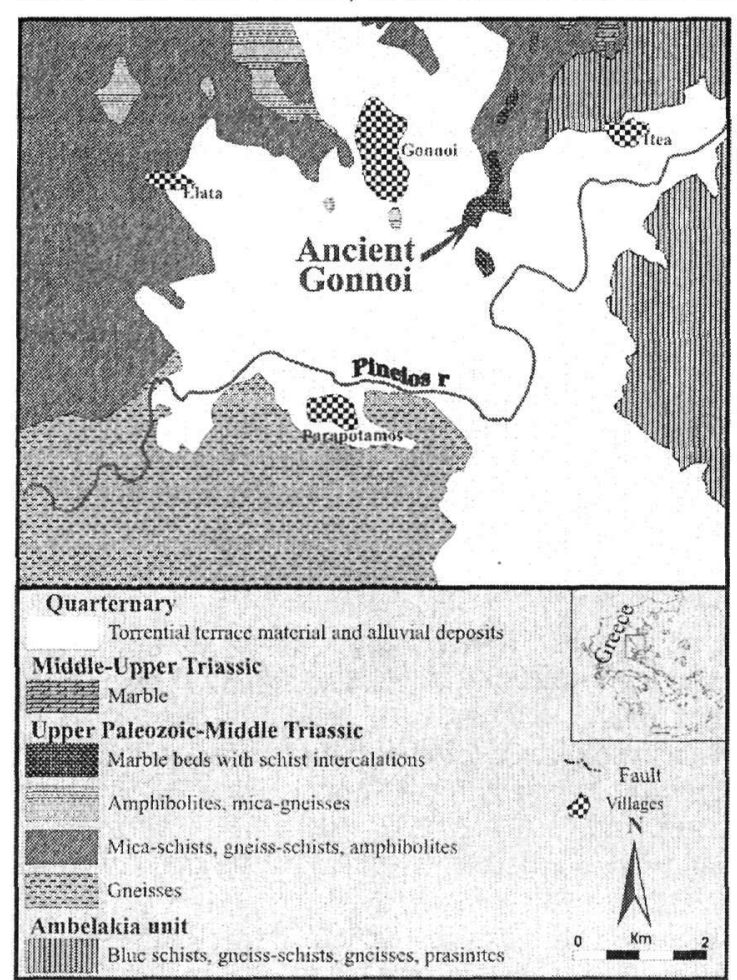

Figure 4. Geological sketch map of the broader area of Ancient Gonnoi quarrying sites (modified after Migiros 1987 , Katsikatsos \& Migiros 1987).
Mt. Olympos. Due to its position the city evidently prospered in the Archaic and Classical periods, as well as in the Hellenistic and Roman time. The city walls and the ruins of the site are still preserved today and are extending on along three hills. Many quarrying works have been observed inside the ancient city.

The area is dominated by metamorphic rocks (Fig. 4) which overlie the Paleozoic crystalline basement of the Pelagonian zone and are folded. These formations have a Pre-Carboniferous to Middle Triassic age and are divided into two units, the lower and the upper (Migiros 1983, Katsikatsos \& Migiros 1987, Caputo 1990). The lower unit consist of gneisses alternated with amphibolites and amphibolitic schists and the upper unit comprise mica-schists, gneiss-schists, amphibolites and marbles with schist intercalations. These marbles of the upper unit outcrop at the Gonnoi area and were exploited during the antiquity.

At a distance of $15 \mathrm{~km}$ north-west of the Gonnoi area, plutonic rocks, represented mainly by granites to granodiorites, intrude the Pelagonian zone. According to Migiros (1983), the magmatic intrusions have affected the surrounding rocks causing a contact metamorphism zone, with 
migmatites and hornfels. The plutonites often contain blocks of metamorphic rocks which have intruded, especially in the contact zone. The size of these blocks ranges from a few tens to a few hundreds of metres

Two quarrying sites were studied in ancient Gonnoi. The first one is found at the western part of the city, close to the walls (Fig. $2 \mathrm{~g}$ ). Two types of white marble exist in this site. The first type (sample: Gonnoi $1 \mathrm{~A}$ ) is a dolomitic marble and a grey colour. Grains are small, with grain size up to 0.5 $\mathrm{mm}$, but in some parts the size reaches $2 \mathrm{~mm}$. The marble consists mainly of dolomite and calcite (Fig. 3c) with white mica as an accessory mineral. The second type (sample: Gonnoi 1B) is a white coarse-grained calcitic marble, with crystal size over $3 \mathrm{~mm}$. This type comprises calcite, with traces of dolomite and chlorite (Fig. 3d). Green-coloured thin orientated stripes consisting mainly of chlorite are often observed.

Some unfinished marble-slabs left in this quarry, reveal the cutting method, which was used in antiquity. For the separation of the block from the parent rock the quarrymen chiselled out cylindrical cavities, $40 \mathrm{~cm}$ long and placed iron wedges. The distance between the cavities ranges from 0.40 to $1.00 \mathrm{~m}$, depending on the hardness of the block and the size of the required block. The cavities were chiselled parallel to the schistosity of the marbles, in order to use the physical properties of the blocks and to eliminate harder and useless work. By hammering the wedges, the quarrymen could easily split off the whole block from the bed-rock. The length of the removed slabs was about $5 \mathrm{~m}$ each, and their width ranged from 0.5 to $1.00 \mathrm{~m}$.

This quarrying site provided blocks for the construction of the city walls, which were built by regular roughly squared stone slabs, during the archaic period. Stählin (1924) refers that this wall circled the NE hill of ancient Gonnoi in the archaic period and part of it was still preserved to $6 \mathrm{~m}$ in height (today only 2-3 $\mathrm{m}$ in height wall is observed).

At the second quarrying site three at least small white marble quarries $(5 \times 2 \times 1 \mathrm{~m}$ in size) are found (Fig. 2h). This site is located at the northern part of the city on the top of a hill. The rock is coarse-grained with crystals up to $5 \mathrm{~mm}$ long, and consists mainly of calcite, with traces of white mica (sample: Gonnoi 3). The schistosity of the marbles is clearly observed in the most parts. Traces of the cutting marks of quarrying tools were not detected, probably because the extraction method was simple and used the physical properties of the rock (e.g. schistosity). The quarrymen probably put the wedges or the crowbars into the open spaces of the cracks and faults and by hammering them they detached the slabs from the parent rock beds. Then they chiselled the blocks and they produced smaller slices, which were used for the wall and buildings construction. These quarrying works are dated to the Hellenistic time, based on Stählin (1924) who refers that the city wall of Gonnoi was extended along the ridge and included the other two hills during $4^{\text {th }}$ century B.C.

\section{ISOTOPIC SIGNATURES}

The isotopic results of 18 fresh marble samples collected from the quarry sites are listed in Table 1 and are plotted in the diagram of figure 5 . The $\delta^{13} \mathrm{C}$ values of the Kastri marble range from +2.71 to $+2.85 \%$ o (average $+2.80 \%, n=6$ ) and the $\delta^{18} \mathrm{O}$ from -4.35 to $-4.75 \%$ o (average $4.51 \%$, $n=6$ ). The results of the isotopic analyses fall in the same range as the isotopic ratios published by Germann et al. (1980), which are $2.46 \% \delta^{13} \mathrm{C}$ and $-5.66 \% \delta^{18} \mathrm{O}$ in average:

Three fresh samples were collected from the Kalochori ancient quarry for carbon and oxygen isotopic analyses (Fig. 5). The $\delta^{13} \mathrm{C}$ values range from +0.84 to $+0.91 \%$ (average $+0.87 \%$, $n=3$ ) and the $\delta^{18} \mathrm{O}$ from -8.59 to $-8.00 \%$ (average $-8.33 \%$, $n=3$ ).

At Gonnoi ancient quarrying sites, the isotopic results are rather heterogeneous. In the first extraction zone, different isotopic ratios have been measured in the two marble types: $+1.05 \% \delta^{13} \mathrm{C}$ and $-4.65 \% \delta^{18} \mathrm{O}$ for Gonnoi $1 \mathrm{~A}$ and $+1.89 \% \delta^{13} \mathrm{C}$ and $-7.97 \%$ o $\delta^{18} \mathrm{O}$ for Gonnoi $1 \mathrm{~B}$ (Fig. 5). In the second quarrying site at Gonnoi, the isotopic analyses showed $\delta^{13} \mathrm{C}$ values: $2.09-2.41 \%$ and $\delta^{18} \mathrm{O}$ values: -2.98 to $-3.32 \%$. This isotopic variation in the samples from ancient Gonnoi is in agreement with the differences in the mineralogical composition and is possibly attributed to the affects of the plutonic rocks which intruded into the Pelagonian zone. 
Table 1. Oxygen and carbon isotope composition $\left(0^{18} \mathrm{O} \%, \delta^{13} \mathrm{C} \%\right.$ ) of white marble from the ancient quarries in Kastri (1-6), Kalochori (7-9) and Gonnoi (10-18).

\begin{tabular}{|c|c|c|c|c|}
\hline \multicolumn{2}{|c|}{$\begin{array}{l}\text { Sampling } \\
\text { site }\end{array}$} & Sample & $\delta^{18} \mathrm{O}$ & $\delta^{13} \mathrm{C}$ \\
\hline \multirow{6}{*}{\multicolumn{2}{|c|}{ Kastri }} & 1 & -4.56 & 2.79 \\
\hline & & 2 & -4.41 & 2.81 \\
\hline & & 3 & -4.75 & 2.71 \\
\hline & & 4 & -4.60 & 2.80 \\
\hline & & 5 & -4.37 & 2.83 \\
\hline & & 6 & -4.35 & 2.85 \\
\hline \multirow{3}{*}{\multicolumn{2}{|c|}{ Kalochori }} & 7 & -8.40 & 0.87 \\
\hline & & 8 & -8.00 & 0.91 \\
\hline & & 9 & -8.59 & 0.84 \\
\hline \multirow{9}{*}{$\begin{array}{l}\overline{0} \\
\text { 동 } \\
\text { o }\end{array}$} & & 10 & -4.64 & 1.01 \\
\hline & $1 \mathrm{~A}$ & 11 & -4.81 & 1.23 \\
\hline & & 12 & -4.49 & 0.91 \\
\hline & & 13 & -7.96 & 1.77 \\
\hline & $1 \mathrm{~B}$ & 14 & -8.31 & 2.02 \\
\hline & & 15 & -7.63 & 1.89 \\
\hline & & 16 & -3.32 & 2.41 \\
\hline & 3 & 17 & -3.05 & 2.09 \\
\hline & & 18 & -2.98 & 2.31 \\
\hline
\end{tabular}

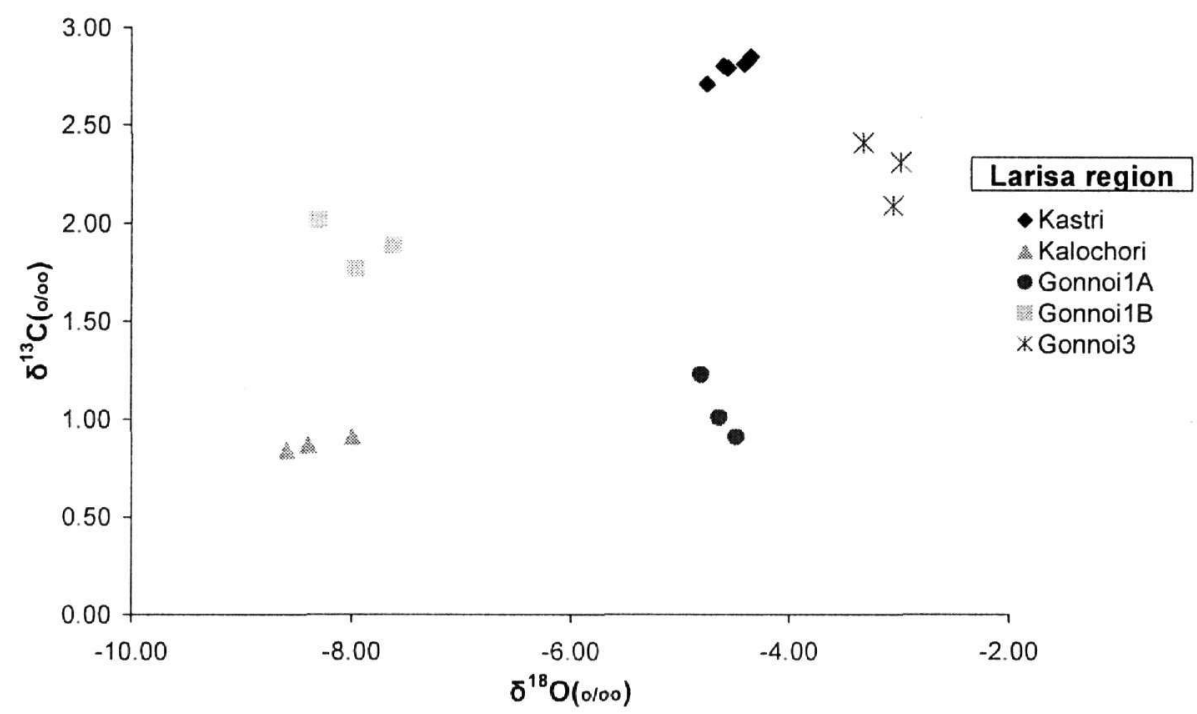

Figure $5 . \delta^{13} \mathrm{C} / \delta^{18} \mathrm{O}$ isotopic clusters of the white marbles in Larisa region.

\section{CONCLUSIONS}

All the ancient quarrying works are recognised as important and potential sites which belong to our natural and cultural heritage. They provide significant information and knowledge concerning the ancient Greek technology, being diachronous historical monuments, which have to be protected and preserved from human activities.

The studied ancient quarrying sites in Larisa area provide significant information regarding the used materials and the applied technology in antiquity. In this direction carbon and oxygen isotopic measurements, combined with petrological and mineralogical results, provide a useful and potential tool in identifying the provenance of ancient marble artifacts. 


\section{REFERENCES}

Caputo R. 1990. Geological and structural study of the recent and active brittle deformation of the NeogeneQuaternary basins of Thessaly (Central Greece). PhD Thesis, University of Thessaloniki, 251p.

Craig H. \& Craig V. 1972. Greek marbles: Determination of provenance by isotopic analyses. Science, 176, 401-403.

Germann K., Holzmann G. \& Winkler F.J. 1980. Determination of marble provenance: Limits of isotopic analyses. Archaeometry, 22, 99-106.

Godfriaux I. 1968. Etude geologique de la region de l' Olympe, Ann. Geol. Pays Hell., 19, 1-271.

Herz N. 1987. Carbon and oxygen isotopic ratios: A data base for classical Greek and Roman marble. Archaeometry, 29, 35-43.

Katerinopoulos A.. Kyriakopoulos K., Del Moro A., Kokkinakis A. \& Giannotti U. 1998. Petrology, geochemistry and $\mathrm{Rb} / \mathrm{Sr}$ age determination of Hercynian granitic rocks from Thessaly, Central Greece. Chern. Erde, 58, 64-79.

Katsikatsos G. \& Migiros G. 1987. Rapsani sheet, Geological map of Greece, 1:50,000, IGME, Athens.

Katsikatsos G., Migiros G., Triantaphyllis M. \& Mettos A. 1986. Geological structure of internal Hellenides. Geol. Geoph. Res. Sp. Issue, 191-212.

Katsikatsos G., Vidakis M. \& Migiros G. 1981. Platycampos sheet, Geological map of Greece, 1:50,000, IGME, Athens.

Kilias A. \& Mountrakis D. 1989. The Pelagonian nappe. Tectonics, metamorphism and magmatism. Bull. Geol. Soc. Greece, XXIII/1, 29-46.

Koroneos A., Soldatos T., Christofides G. \& Gerouki F. 2000. Comparative geochemical study of plutonites from the northern pelagonian zone. In Proc. 1st Conf. Commit. Econ. Geol., Mineral., Geoch., 243-260.

Koukouvelas I. 1994. Flow partitioning during nappe motion in the Aghia marble, Thessaly, Greece. Bull. Geol. Soc. Greece, XXX/2, 159-165.

Lazzarini L., Moschini G. \& Stievano B.M. 1980. A contribution to the identification of Italian, Greek and Anatolian marbles through a petrological study and the evaluation of $\mathrm{Ca} / \mathrm{Sr}$ ratio. Archaeometry, 22, 173-183.

Maniatis Y. \& Polikreti K. 2000. White marbles in antiquity: provenance with use of physicochemical techniques, In: The Building Stone in Monuments, (eds) Varti-Matarangas M \& Katsikis Y., IGME, Athens, 119-131.

Melfos V. \& Vavelidis M. 2000. The ancient quarries in Maronia, Rhodope prefecture. Thessalonikians Polis, 2, 63-76.

Melfos V., Vavelidis M. \& Theodorikas S. 2002. Preservation of the Greek Cultural Heritage: A study of the geology and extraction techniques of two ancient quarries, Larisa prefecture, Thessaly, Greece. In: Proc. Int. Conf. "Protection and Restoration of the Environment VI", (eds) Kungolos et al., 1535-1544.

Migiros G. 1983. Geological study of the Kato Olympos area Thessaly. PhD Thesis, University of Patras, 204p.

Migiros G. 1987. Gonnoi sheet, Geological map of Greece, 1:50,000. IGME, Athens.

Orlandos A. 1958. The building materials of the ancient Greeks, Library of the Athenian Archaeological Society, Athens, 426p.

Polikreti K. \& Maniatis Y. 2001. A new methodology for marble provenance investigation based on EPR spectroscopy. Archaeometry, 43, 1-21.

Reischman T., Kostopoulos D.K., Loos S., Anders B., Avgerinas A. \& Sklavounos S.A. 2001. Late Paleozoic magmatism in the basement rocks southwest of Mt. Olympos, Central Pelagonian zone, Greece. Bull. Geol. Soc. Greece, XXXIV/3, 985-993.

Stählin F. 1924. Das Hellenische Thessalien. Verlag Von J. Engelhorns Nachf, Stuttgart, (Greek translation, Kyriakidis brothers, Thessaloniki, 2002), 428p.

Tsirambides A. 1996. The greek marbles and other decorative stones, University Studio Press, Thessaloniki, $310 \mathrm{p}$. 